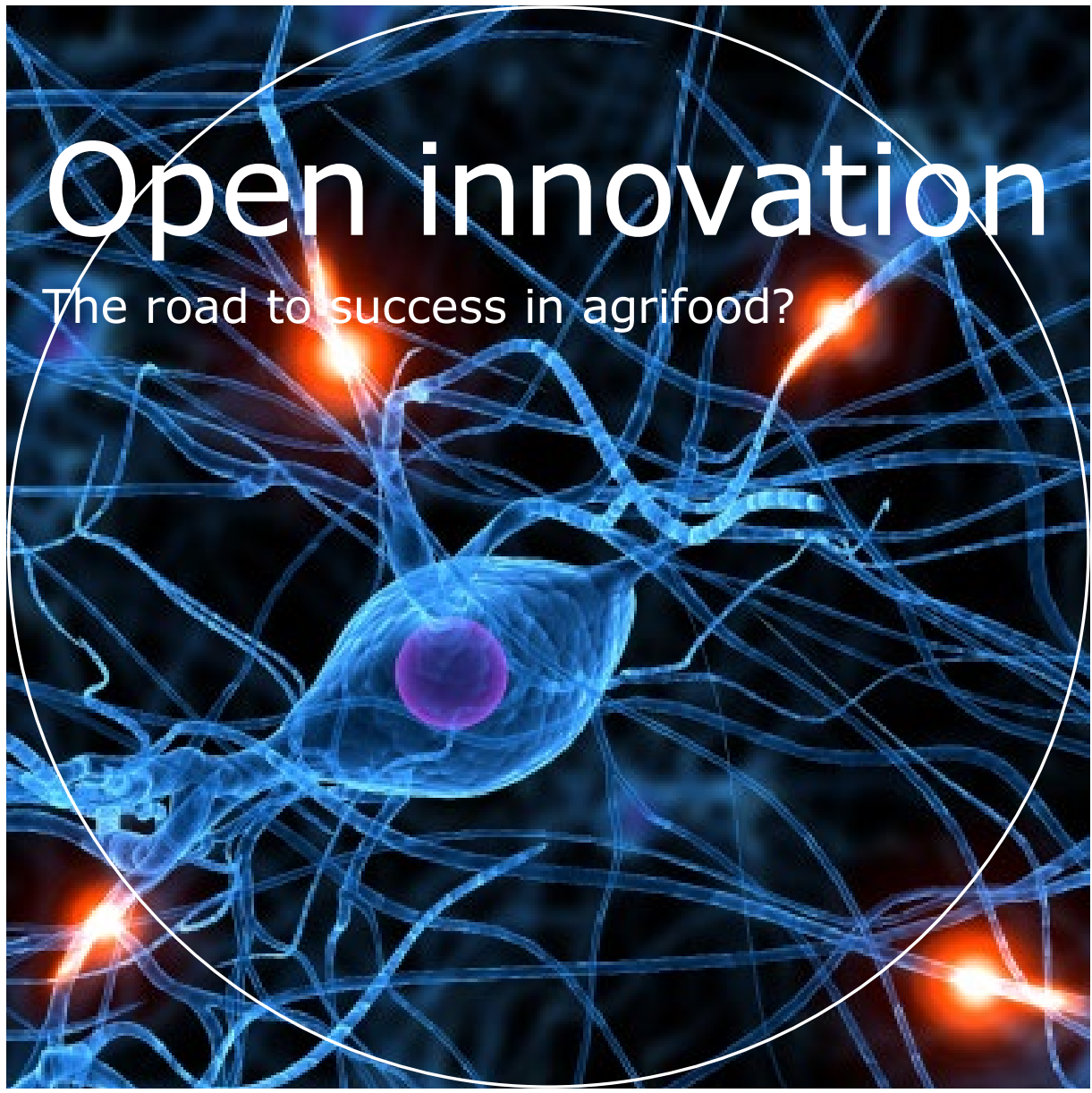

Prof.dr S.W.F. Omta

Farewell address upon retiring as Professor of Management Studies at Wageningen University \& Research on 26 October 2017 


\section{Open innovation}

The road to success in agrifood?

\section{Prof.dr S.W.F. Omta}

Farewell address upon retiring as Professor of Management Studies at Wageningen University \& Research on 26 October 2017 
DOI HTTPS://DOI.ORG/10.18174/426017

ISBN 978-94-6343-720-2 


\section{Open Innovation \\ The road to success in agrifood?}

Dear colleagues, family and friends, I want to thank you all for coming to attend my farewell address.

When I came to Wageningen from the University of Groningen in the year 2000, I brought quite some experience in innovation in high-tech sectors, especially in electronics, bearings and the pharmaceutical industry. I had realised that, at the turn of the century, the world had developed into a network economy, exemplified by the picture of the human brain neuron with all its connections, as depicted on the invitation you received for my farewell address. Countries were becoming interconnected and competition was no longer local, but increasingly on a global scale. In this global network economy, high-tech companies could no longer focus on short-term returns alone. A long-term strategic vision had become a prerequisite for future success. Knowledge and flexibility had become key factors; thus investments in innovation and knowledge development were recognised as indispensable. I also learnt that in order to arrive at successful innovations, public-private collaboration between businesses, knowledge institutions and government was essential.

This made the long-term success of these high-tech firms increasingly dependent on open innovation, the degree to which they were able to collaborate in both domestic and international networks.

When I accepted the position of full professor in Business Administration, here at Wageningen University, I was convinced that the agrifood industry would be no exception, especially when I noticed how intense the competition was and how demanding the consumers were. This, according to me, called for multidisciplinary collaboration to find possible solutions. So I enthusiastically told my senior colleagues in Wageningen about my experience with open innovation as a way for agrifood companies to cope with the challenges in national and international competition. However, in the year 2000 no one seemed the least impressed. They referred to the famous statement of the former French President George Pompidou: 'There are three sure roads to ruin: women, gambling and technicians 
(thus through innovation). The most enjoyable one is with women, the quickest one is with gambling, but the surest one is with technicians.' They told me: 'Onno, stop with research into innovation. Food consumers are very conservative; they don't like innovations. And open innovation is totally out of the question, most agrifood companies are small family-owned firms that don't want to work together.'

So there I was; no one seemed in any way interested in my research ideas. I did not know then, of course, as I do now, how innovation and open innovation would develop from the year 2000; even the term open innovation was only coined by Chesbrough in 2003. Today, we talk already about Open Innovation 2.0 at large Open Innovation Forums with participation of industry, government and Academia.

I want to use this farewell address to lead you along the path that I walked in Wageningen during the past 17 years. Let me start my journey by sharing with you three important questions I had to answer when I came to Wageningen. The first question: Is innovation in general, and open innovation in particular, really important for the long-term survival of companies or are these just year-200o hypes? The next question: If innovation is indeed not a hype, and if companies that use innovation and open innovation are indeed more successful than non-innovators, how important is innovation and open innovation for the agrifood industry, generally regarded as a more traditional sector? And the third one: If innovation and open innovation are indeed important for companies in the agrifood sector, what is the best way to manage the innovation activities, taking into account that $90 \%$ are small and medium-sized enterprises (SMEs)? During my journey I will specifically refer to the research results from my own PhD students and the staff from the Management Studies Group to answer these questions.

Let me continue my journey by discussing the first part of my first question: What is innovation and how important is innovation for companies? The popularity and wide applicability of the term 'innovation' has resulted in a proliferation of meanings. The recent book of Godin (2017) is the most thorough study of the development of the word and the models of innovation. In our research group we base ourselves on the evolutionary-economics approach inspired by the work of the famous economist Joseph Schumpeter, and we use the broad definition of innovation that he already provided in 1934. For Schumpeter, innovation implies not only the introduction of new products, but also the successful commercialisation of new combinations, based on the application of new materials and components, the introduction of new processes, the opening of new markets or the introduction of new organisational forms. Essentially, innovation is about change; changes in the products and services of a company and in the way the company produces them, but 
also changes in business models (e.g. Osterwalder and Pigneur (2010), management techniques, and organisational structures (Hamel and Prahalad, 1994). The degree of novelty can differ from incremental innovations, including minor changes, for instance line extensions, to radical innovations, including breakthroughs, which are new to the market but often even new to the world (Tidd et al., 2001), and even disruptive innovations, displacing established market-leading firms, products, and alliances (Christensen et al. 2015). Later in my address I will come back to the question how important radical, breakthrough and even disruptive innovations have become for the agrifood sector.

Now I want to continue my journey with the question whether or not innovation is really important for the long-term survival of companies? By now, it has become perfectly clear that innovation is indeed important and certainly not a year-200o hype. Nowadays, innovation is widely recognised as one of the major drivers of business success. The American Management Association (AMA) conducted a survey among approximately 1,400 US top executives. More than $90 \%$ of them considered innovation to be (extremely) important for their company's long-term survival, with over $95 \%$ believing that this will still be the case in ten years' time. It was concluded that customer centricity, teamwork, and cooperation, together with the appropriate resources (time and money) are the most important drivers of innovation.

Unfortunately, the same survey revealed that $85 \%$ of the executives did not consider their firms to be very successful at executing the innovation process (Jamrog, 2006).

This is not astonishing, if we realise how difficult the innovation process really is. As Owen et al. (2013) correctly indicate: 'Innovation is not a simple, linear model with clear lines of sight from invention to impact... It is an undulating path, sometimes with dead ends, involving many, often loosely-connected actors.'

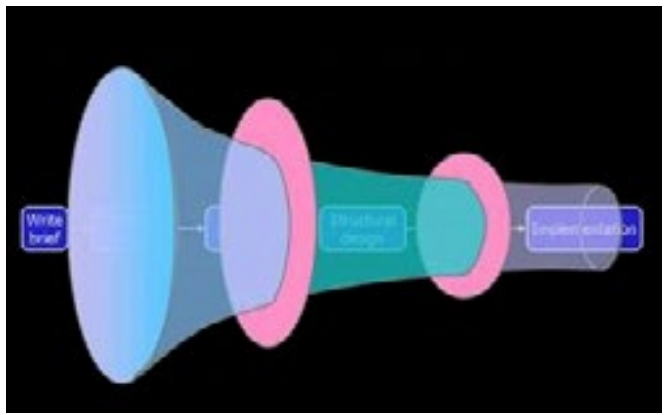

Figure 1: The innovation funnel 
Creativity is especially important at the start of the innovation funnel also known as the 'fuzzy front end'. The funnel is wide open, 3,ooo rough ideas are weeded down to about 300 ideas worth further investigation. This investigation results in about 125 research projects, from which nine development projects can be expected. These are likely to generate four commercialisation projects, leading to 1.7 product launches. Given a $60 \%$ success rate among launches, these 1.7 launches translate on average into one commercially successful new product out of the original 3,0oo ideas. So it is very understandable that CEOs oriented on short-term financial returns are reluctant to invest in innovation.

Many problems occur when the results of one phase of the innovation process are transferred to the next one (e.g. Tidd, 2014). To overcome these communication problems, many studies have pointed to the importance of self-managing crossfunctional teams (e.g. Griffin, 1997, Annosi et al., 2017). Moving from the traditional "relay race" approach, in which one group of functional specialists transfer their completed results to the next stage, to the "rugby approach", in which a multidisciplinary team, with team members from Research and Development (R\&D), finance, marketing, manufacturing and procurement, work closely together from the earliest stages of an innovation project until the product actually gets introduced to the market. And all this is even within just one company!

Now I shall continue my journey by focusing on cooperation outside the boundaries of the company, by answering the second part of my first question: What is open innovation and is there empirical evidence that open innovation is really working? In the past few years, the term open innovation has become a key concept. Figure 2 shows that in open innovation the boundaries of the innovation funnel become blurred. Ideas and technologies are not only developed internally, but also originate outside the company. The firm licenses in from other firms, and also licenses its own knowledge out to companies that can use it to create better value. Spin-off companies put products on the market on the basis of technologies not considered as being core by the mother company. At the same time, the mother company buys products in order to complement its product portfolio. (Ahuja, 2000, Chesbrough et. al., 2006, Gilsing et al., 2008; Phelps, 2010 and Tasselli et al., 2015). 


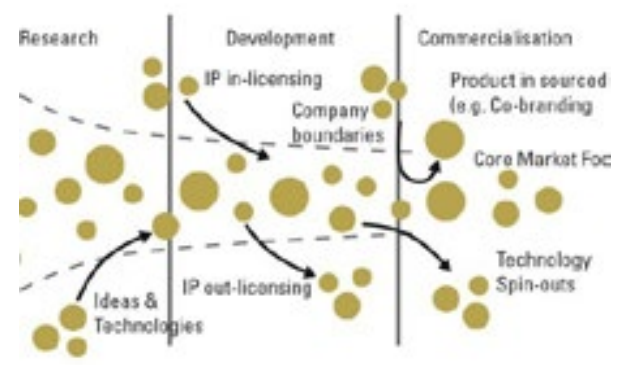

Figure 2: Open innovation

A large-scale study by Ebersberger and Herstad (2011) in Europe, showed that open innovation has a positive impact on the innovative potential of a company. Clearly, open innovation is also on the political agenda. Last month I was informed that currently the Joint Institute for Innovation Policy conducts a study on Knowledge Transfer and Open Innovation for the European Commission.

Open innovation theory is situated within the broader open innovation ecosystems paradigm (recent discussions by Traitler et al., 2011, Adner \& Kapoor, 2016 and Chesbrough, 2017). The ecosystem concept has been adopted from ecology, which is the study of interactions and relationships among living organisms, and with the elements within their habitat. In the open innovation ecosystems paradigm it includes all collaborative arrangements through which research organisations enhance and accelerate their innovation processes through co-innovation (Von Hippel, 1988). Famous examples of open innovation ecosystems are: Silicon Valley, The Boston Innovation Ecosystem and, closer to home, the High Tech Campus in Eindhoven.

When I present a keynote in the USA, Europe, China or South America, I often refer to the Food Valley as the Dutch food equivalent of Silicon Valley. Food Valley, including the Wageningen Campus and the planned World Food Centre in Ede, is rapidly evolving into an open innovation ecosystem in which university chair groups, research institutes, R\&D Centres, such as FrieslandCampina R\&D and the planned Unilever Global Food Innovation Centre, work closely together with SMEs and high-tech start-ups, e.g. in the StartLife Incubation Centre. My former PhD student and current lecturer Facility Management, Herman Kok, has advised the Wageningen Campus based on his experience with the influence of the build environment on the learning experience of students. The numbers in the Food Valley Open Innovation Ecosystem are really staggering: 15,000 scientists, 20 research institutes, 1,440 food related and 70 science related firms. 
However, for many companies the attempt at ecosystem innovation has been a costly failure. This is because, along with new opportunities, open innovation ecosystems also present a new set of risks, new dependencies that can derail a firm's best efforts. In 1999, I already pointed at the 'Dark side of cooperation', based on the results of my study on failed high-tech collaborations among companies from the USA, Japan, the Netherlands and Ireland (Omta and Van Rossum, 1999). In these failed collaborations, major problems were encountered in the fields of security, costeffectiveness and relevance of results, risks of knowledge spill-over and high coordination costs.

How staggering the coordination costs could rise was shown by my research in 1998 at Philips Electronics. The study revealed an exponential relationship between project complexity and development costs (Gerritsma and Omta 1998, see Figure 3). The results were quite unexpected for the management of Philips, who had clearly underestimated the communication and coordination costs, especially those related to contacts with suppliers, and among the various business units. Later we found the same relationship when we compared the effectiveness of open innovation projects of different size.

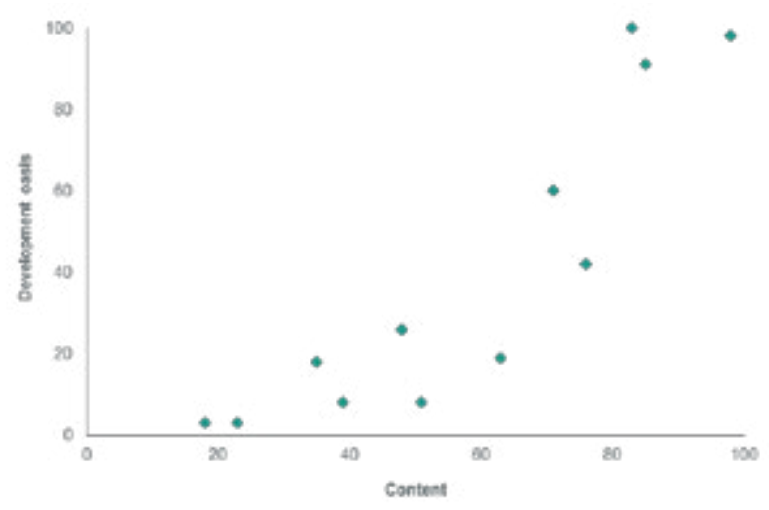

Figure 3: RED project complexity versus development costs

Also, in a number of cases, competitors were strengthened or even newly created. Working closely together with network partners also reduced the possibilities to relate to companies outside the network. Especially in high-tech environments, knowledge and skills become quickly obsolete, diminishing the value of current partners, and demanding collaboration with new ones (see also Koka et al., 2006; Gilsing \& Nooteboom, 2006, Foss et al., 2012). These challenges gave rise to important research questions which members of our group have worked on in the past 17 years. 
- How do firms manage opportunities and risks in their open innovation networks?

- What is the optimal degree of openness and how to ensure that open innovation networks can be reconfigured if needed?

- How to best make the transition from precompetitive to competitive cooperation, i.e. from a more open innovation network, necessary for knowledge creation, to a more closed supply-chain network, necessary for knowledge exploitation? So, to answer my first question: open innovation works in high-tech sectors, but it is associated with serious managerial challenges. Let me continue my journey by focusing on my second question: Is innovation also important for the agrifood industry?

Let me first focus on the special position of the agrifood sector in the Netherlands. As most of you probably know, the Netherlands is the second exporter of agrifood products in the world, after the United States. In 2016, exports amounted to 94 billion euros, $77 \%$ going to other European countries. Important for this address is the great international interest in Dutch high-tech agrifood innovations. Exports in this area amounted to nearly 9 billion euros, including energy-efficient greenhouses, precision agricultural systems and new discoveries that make crops more resistant (OECD, 2015 and agroberichtenbuitenland.nl, 22-01-2017). So it will not come as a surprise to you that already in 2009, we found in a study among leading Dutch food-processing companies that innovation has become essential for their business performance and long-term survival on the market (Fortuin and Omta, 2009).

The importance attached to innovation by the company's executives, and the quality of the innovation processes, as assessed by the engineering staff, showed a significant positive correlation with the company's financial position relative to its closest competitors.

This is the Netherlands, of course, famous for its high-tech agriculture. The question remains, is innovation equally important for artisanal agrifood sectors, which are often regarded as more low-tech (e.g. Triguero et al., 2013). Bianca Kühne (2011) showed that innovations are indeed also important in artisanal sectors, such as Italian cheese and ham, Belgian beer and Hungarian sausages, which were formerly considered as very traditional. In the Handbook of Innovation in the Food and Drink Industry (Rama (ed.), 2008), Mytelka and Goertzen counted 28 viticulture innovations. Even the mere existence of such handbooks demonstrates how important innovation has become in the agrifood industry (Omta and Folstar, 2005). And this importance is increasing. Karen Janssen (2011) showed that currently there are even many radical innovations in the agrifood industry. In the period 2005-2010, she counted the market launch of 12 breakthrough innovations in the Netherlands, including the plant sterol-based LDL-cholesterol lowering Becel Proactiv. 
So the situation has changed dramatically. Currently, even the European Commission (2016) regards agrifood innovation as essential for ensuring long-term food security and sustainability. Take a look at the website www.world-foodinnovations. com to get an idea of the staggering number of innovations in the global food sector, reaching from food ingredients, starting materials and seeds, food and feed products, to processing technology, equipment and packaging.

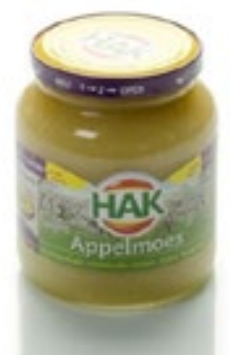

Figuur 4: The Hak 1-2 Open lid.

'De Gouden Noot' Winner for the most innovative packaging in 2012

The importance of packaging for the agrifood sector is shown by the fact that one-third of all packages in the world are food related. Until last year I was chairman of the jury of 20 professionals for 'De Gouden Noot', the biannual international award for the most innovative packaging. 'De Gouden Noot' has been issued since 1958 by the Netherlands Packaging Centre. Food-related 'Gouden Noot' winners of the past ten years are the Culidish, the well-known HAK 1-2 Open lid and the BeeMagicTray.

The increased importance of innovation in the agrifood industry is also shown by the fact that up to the year 2000, patents were only used sporadically. This situation has changed dramatically. In 2013 Unilever filed 178, Intervet 46 and Nutricia 38 European patents. Also the more than 800 patents that Nestlé has filed to protect the Nespresso coffee-making system, shows how much has changed since the year 2000. As an R\&D director from a medium-sized company told me: 'Especially in the last three years, the patenting of products and processes has expanded so rapidly that this can be called the biggest development in the past decade.' 
So far I have looked back in this address, now I want to take a short look into the future. By the way, did you know, that already back in 1931, Winston Churchill wrote in his futuristic article 'Fifty years hence' in the Strand Magazine about the expected developments in the agrifood industry: 'We shall escape the absurdity of growing a whole chicken in order to eat the breast or wing, by growing these parts separately under a suitable medium.'

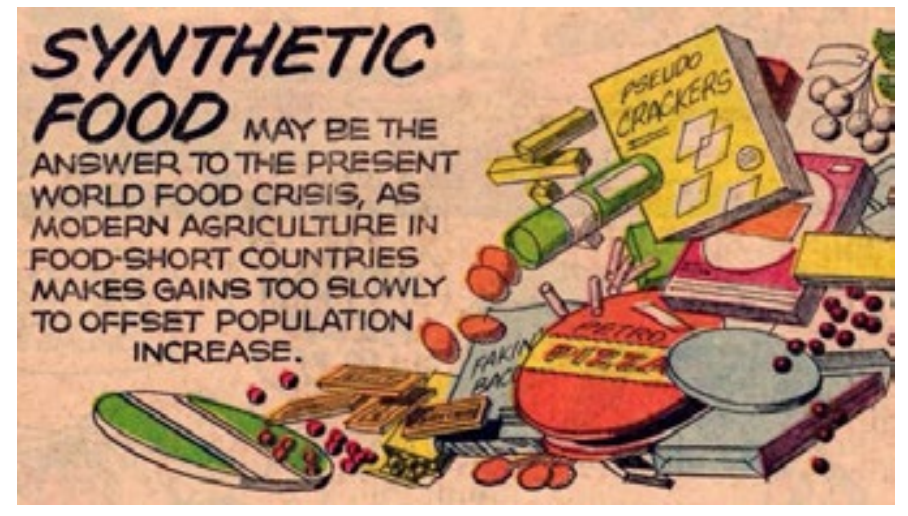

Figure 5: Comic Strip 'Our New Age' (1965)

The Comic Strip 'Our New Age' (Figure 5) shows that, already in 1965, synthetic foods were then seen as a possible solution for the envisioned world food crisis. And now, 86 and 52 years later, respectively, these visions are not so far-fetched anymore. I will now elaborate on three disruptive innovations that are already fundamentally changing the agricultural system as we know it, namely cellular agriculture, vertical farming and big data. I also want to highlight the high-tech start-ups that want to bring these disruptive innovations to the market. Our group is helping such hightech start-ups by providing them with the lessons-learned based on the results of comparative studies we conducted among successful and less successful start-up companies. First I want to focus on cellular agriculture.

An important example of cellular agriculture is cultured meat; meat that is grown from embryonic stem cells. The Maastricht-based start-up Mosa Meat expects to be able to produce cultured meat using muscle-stem cells in about three years, while the Brooklyn-based start-up Modern Meadow is currently working on producing cultured leather. 


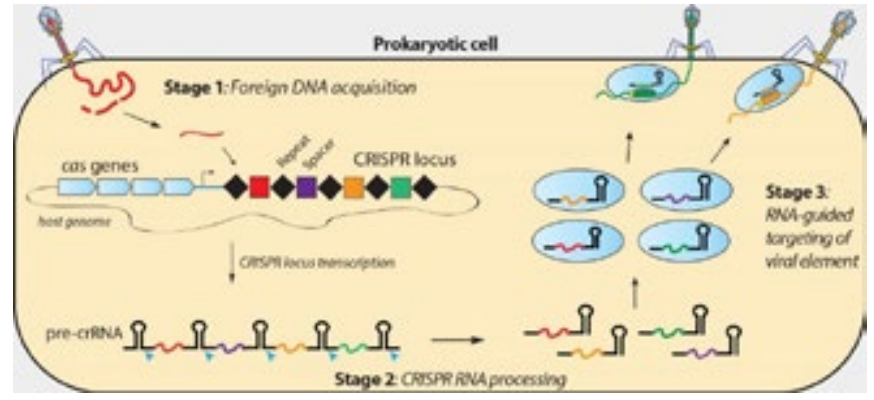

Figure 6: The working of CRISPR-Cas in a prokaryotic cell (bacteria) against the attack of a virus (the rocket type elements on the prokaryotic cell)

A far-reaching new technology in cellular agriculture is the CRISPR-Cas system. Since about five years, this system has made it possible to relatively easily modify individual genes within plant, animal and human genomes. The CRISPR-Cas system is an immune system of bacteria that confers resistance to foreign genomes (Ribonucleic acid (RNA) and Deoxyribonucleic acid (DNA) from viruses or other bacteria (see Figure 6). A simple version of the CRISPR-Cas system, CRISPR-Casy is used to specifically modify genomes. There are high expectations that it will be possible to use this new technology to revolutionize the agrifood sector. For instance, the Berkeley-based start-up Perfect Day wants to use this technology to produce yogurt, cheese and ice cream produced by yeasts instead of cows' milk, by using CRISPR-Cas9 to transfer the genes for the production of the milk proteins casein and whey from cow-DNA to yeast-DNA.

However, these very promising developments are also heavily contested, especially here in Europe; we speak about Genetically Modified Organisms (GMOs).

In this discussion the difference between Transgenesis and Cisgenesis is important (e.g. Telem et al. 2013). While in Transgenesis genes from another species are transferred, e.g. from a cow into a yeast as in the Perfect Day example, in Cisgenesis genes of another variety of the same species are transferred, for instance R-genes against Late blight are transferred from the DNA of wild potato species into the DNA of cultivated potato species. Late blight is world-wide the most devastating potato disease, caused by Phytophthora infestans. So it is clear that important steps forward can be taken here. But there is a lot of discussion; adversaries even speak of the 'Cisgenesis lobby'. Together with the chair group Philosophy, members of our group are working on these issues under the umbrella of social entre $\neg$ preneurship and responsible innovation (Lubberink et al., 2017 and Ploum et al., 2017). Now let me move to vertical farming; the practice of producing food in vertically stacked layers. There are many kinds of vertical farms, differing in the type 
and square footage of buildings they occupy, and the mode of light used, either daylight or LED-light. Compared to traditional agriculture, vertical farming uses up to $70 \%$ to even $95 \%$ less water and up to $90 \%$ less land, while harvesting up to $80 \%$ more per acre. Special LED-light recipes can be used to improve taste, and increase the vitamin content. Vertical farming is spreading fast, especially in heavily populated metropolitan areas. In a former factory of Sony in Miyagi, Japan, 17,500 LED lamps produce 10,000 crops of organic lettuce per day. In Singapore, Panasonic produces over 80 tons of vegetables by means of indoor farming. The main problem to be solved is the amount of energy needed. The University of Bonn has calculated that vertical farming using LED-light consumes about 1 megaton per ton vegetables and fruits. Wind and solar power will certainly be needed to provide this amount of energy in a sustainable way. Frank et al. (2017) concluded that agriculture and forestry together contribute approximately $25 \%$ of the human-caused greenhouse gas emissions. If global warming is to be kept below $1.5^{\circ} \mathrm{C}$, the target set by the Paris agreement, the agrifood sector will have to contribute significantly. Researchers of our group, together with the Environmental Sciences department, play a pivotal role in advising which climate smart agricultural measures best to be taken, e.g. by studying the effects of the introduction of different eco-innovations (e.g. Hasler et al., 2016) and by comparing the Carbon footprint of the different systems of vertical farming in Metropolitan areas.

Also big data play an important role in mitigating the adverse effects of climate change. And luckily enough, we can say that big data play an important role already in today's Dutch agriculture. I am a member of the Supervisory Board of Scholtenszathe Estate, one of the largest arable farms in the Netherlands. They are already making extensive use of smart fertilization and precision agriculture and have experimented with robots and drones.

Thus I showed you that the answer to my question whether innovation is really important for the agrifood sector, is clearly positive and it is clear that its importance will only grow in future.

Let me now move to my next question: Is there a role to play for open innovation to turn these great opportunities into business reality? First the good news, many studies have shown that open innovation is really working, both for food multinationals as well as for Food SMEs (see also Knudsen, 2007, Sarkar and Costa, 2008). An R\&D director of a food multinational in the dairy industry formulated the fundamental change in thinking as follows: 'Formerly my lab was my world, now the world is my lab.' 


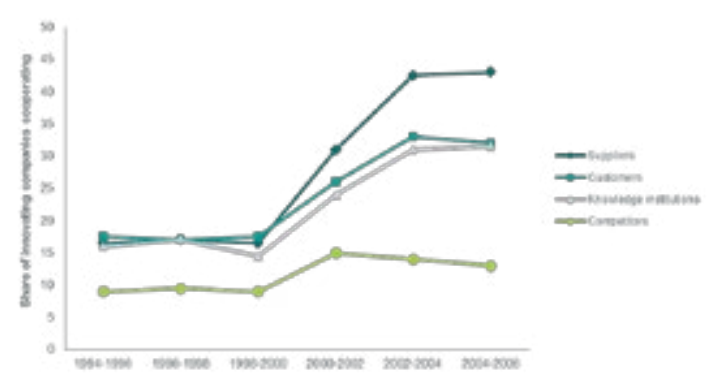

Figure 7: Percentage of innovative food firms that collaborate with various partners in open innovation projects

Let me give you a few concrete examples of the contributions of my PhDs to the field of open innovation in the agrifood sector. In 2009, my former PhD student Maarten Batterink looked deeper into the development of open innovation in the Dutch agrifood sector, based on the responses in six serial Community Innovation Surveys (CIS), filled in by more than 1,300 innovative agrifood companies per survey. Figure 7 clearly shows that building and maintaining an external network is now crucial for the survival of innovative agrifood firms. Interestingly, the same CIS data reveal that the pattern of collaboration of innovative agrifood firms in terms of the increase in time, and the distribution among the various types of partners, is very comparable to that in high-tech sectors (Wubben et al. 2015).

In 2015, my former PhD student Sabine Bornkessel showed that the boundaries between the agrifood and the pharmaceutical industry are rapidly blurring, especially in the area of functional foods. As Figure 8 shows, agrifood firms involved in probiotics are patenting increasingly frequent, both independently and in partnership with pharmaceutical companies. The development of probiotics really started after the market launch in 1987 of 'Activia' by Danone, the first yogurt based on probiotics. We can see that the increase in number of patents since the mid of the 1990 s has been almost exponential, with an obvious acceleration of the contribution of agrifood companies since 2005. Furthermore, from 2008 onwards, we see a fast rise of the number of patents based on collaboration between food and pharmaceuticals firms. In recent years, though, the European Food Safety Authority (EFSA) has dismissed many health claims, to the disappointment of many agrifood firms. 


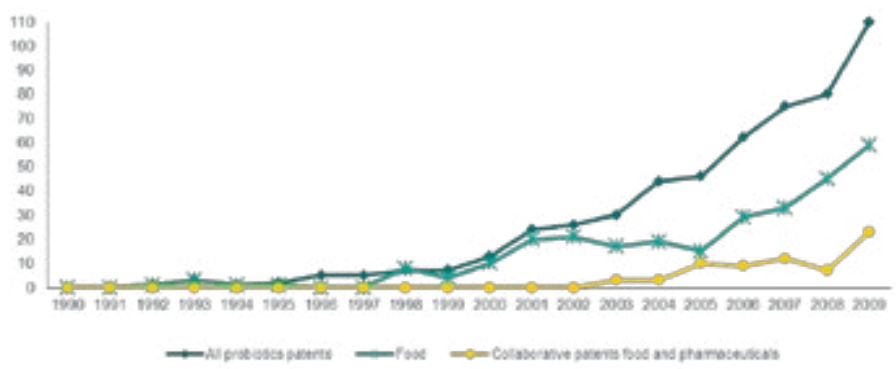

Figure 8: Number of probiotics patents from 1990 to 2010. Adapted from Bornkessel et al. (2015)

My former PhD student Christine Enzing studied about 130 innovative agrifood products launched to the market around the year 2000. Most products proved to be very successful in the long run; nearly two-thirds of them were still on the market seven years after market introduction. This outcome was unexpected, as there is little mention in the professional literature of new agrifood products showing a long survival time on the market (Buisson, 1995; Rudolph, 1995; Lord, 2000). Apparently, the radical character of most of these products increased their chances of survival. Another interesting result was that the products developed in open innovation projects were more successful than those that came from the firm's own R\&D. Especially the innovations that resulted from cooperation with supply chain partners, ingredient suppliers in particular, and involving universities and research institutes, performed particularly well (Enzing et al., 2011).

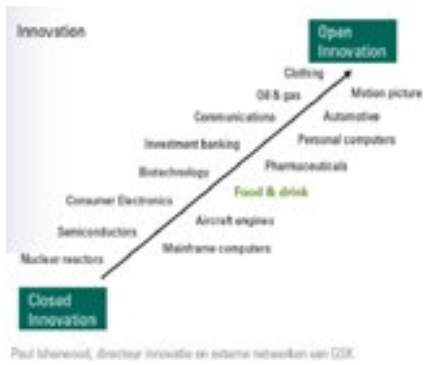

Figure 9: Various industries arranged on a continuum from closed to open innovation. Source: Paul Isherwood, Director Innovation and External Networks at GSK

Figure 9 shows how far the agrifood sector has come by now. You can find the sector just below the middle of the continuum from closed innovation to open innovation; on par with consumer electronics, and just behind pharmaceuticals and biotechnology, but ahead of semiconductors (see also Medeiros et al., 2016). 
This brings me to my last question: Are there lessons to be learned for agrifood SMEs how to conduct open innovation projects? And then the bad news, innovative agrifood SMEs still have a lot to learn. When we compared the percentage of successful open innovation projects of high-tech SMES with that of innovative agrifood SMEs, we had to conclude that high-tech SMEs reached a level of $80 \%$ to $90 \%$ successful projects, whereas this percentage was only $40 \%$ to $50 \%$ for innovative agrifood SMEs (Omta et al. 2017). The problems encountered by agrifood managers conducting open innovation projects are exemplified by two quotes from the research of my former PhD student Elise du Chatenier (Chatenier et al. 2010).

- 'It is difficult to provide immediate feedback to your customer, especially if you depend on him and you do not want to lose business.'

- 'Some of our competitors seem to participate in open innovation projects mainly for strategic reasons.'

Our PhDs (e.g. Haverkamp et al., 2010, Wever et al., 2012, Garbade et al., 2013, Sabidussi et al., 2014, Grekova et al., 2014 and 2016, Scholten et al., 2015, Khodaei et al., 2016, Nuhoff-Isakhanyan et al., 2017) could not only contribute significantly to the scientific literature in the fields of transaction cost economics (e.g. Teece, 1986), the dynamic capabilities perspective (Nooteboom, 2004 and Teece, 2007) and the knowledge governance approach (Grandori, 2001, Foss et al., 2012, Gulati and Srivastava, 2014, Materia et al., 2017), but could also provide input to support innovative agrifood SMEs. In 2013, we published the book: 'Open Innovation in the Food Industry: An Evidence-Based Guide' (Omta et al., 2013) and the NetGrow Toolbox, (Fortuin and Omta eds., 2014). We shared the outcomes in a number of sessions with over 100 agrifood SMEs in the Netherlands and the EU. This book provides answers to questions such as:

- How to best select collaboration partners?

- What are the dos and don'ts for collaboration in open innovation trajectories?

- Which projects are suitable to be carried out in an open innovation setting, and which projects could better be executed in-house?

Our group used its research findings to develop two tools to assist agrifood managers to conduct their open innovation projects successfully; the Open Innovation Matrix and the Wageningen Innovation Assessment Toolkit (WIAT). The Open Innovation Matrix helps managers to decide whether the innovation trajectory can best be conducted in-house, in collaboration with partners, or outsourced. 


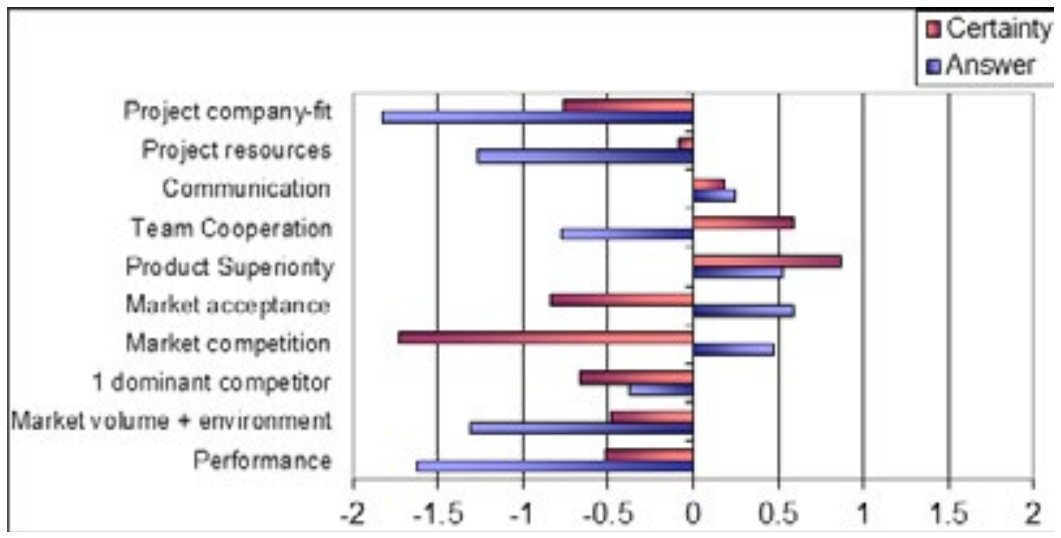

Figure 10: Example of the presentation of a problematic project in WIATT

WIAT shows the success potential of an innovation project by comparing its innovation profile, drafted by the team members of that project, with a large database of innovation profiles from earlier successful and failed innovation projects. WIAT thus provides early warning signals that can be used in a go-no go meeting. WIAT is based on earlier work of Cooper (1999) and my former PhD student Jan Hollander (2002). Next to being an important support tool for agrifood companies, the results could be used to get a deeper understanding of the dynamics of success and failure in innovation projects, for instance published by my former PhD student Mersiha Tepić (Tepić et al., 2013). Figure 1o provides an example of the presentation at a go-no go meeting of an innovation project that, according to the assessment of the project-team members compared to the database, has a high potential to fail.

This brings me to the answer to my last question: Are there lessons to be learned for agrifood SMEs how best to conduct open innovation projects? Our comparative study (Omta et al. 2017) clearly revealed that innovative agrifood SMEs can learn important lessons from high-tech SMEs. I want to point here to the most important one. Partnership management is all about creating trust. Formal agreements can provide a platform that paves the way for building a high level of trust, necessary for a strong cooperation (Denolf et al., 2015). Well-established upfront agreements about the overall strategy, the expected contribution of each of the partners, the ownership and risk division and the Key Performance Indicators and the Key Deliverables for each stage of the cooperation, can build up such a platform (Flipse et al. 2013. Precisely because it is so important to reach agreements in advance on property rights and confidentiality, it is remarkable that many innovative agrifood SMEs reported omitting this phase in the preparation of their open innovation trajectories. Considering the important role of creating a platform for trust, we suggest that this 
important phase should be taken more seriously by innovative agrifood SMEs, as is already the case in the high-tech seed sector, as studied by my former PhD student Zhen Liu (Liu et al., 2015).

Let me end my journey by moving to what has happened to my chair group in the past 17 years. In terms of orientation and number of staff members a lot has changed since the year 2000. We started out with 1o Dutch staff members and one PhD student. Now our staff amounts to around 50 staff members, Post docs and PhD students; about $50 \%$ stemming from foreign countries.

In 2015, the research quality of our chair group was acknowledged as excellent by an international peer review committee. Our group is also well-embedded in the academic, industrial and governmental networks to play a pivotal role in the academic and societal discussions regarding the challenges of climate change and globalisation, while providing the science-based management tools needed to prevent and mitigate these challenges.

I am happy to say that the increased orientation on research and knowledge valorisation has not jeopardised our focus on education. Our chair group plays an important role in the Bachelor Business and Consumer Studies and the Master Management, Economics and Consumer Studies. The number of bachelor and master students is increasing fast. It is our policy to keep the learning environment as student-oriented as possible despite these increasing numbers. To achieve this, our lecturers strive to create learning communities, using new techniques, such as Massive Open Online Courses, the so-called MOOCs.

Early-on, we realised the importance of entrepreneurship education to prepare our students to start their own company. In 2013, together with the chair group of Education and Competence Studies, we founded the Entrepreneurship master track which is open to all students of Wageningen University. Our chair group also houses the only Dutch Scientific Master Specialisation in Facility Management. Over the years, I have attached great importance to cooperation with the technical departments as reflected in our contribution to a number of master programmes for technical students, such as the master programmes in Food Quality Management; Food, Innovation and Management, and Environmental Management. Currently, about 100 students write their scientific master thesis and/or their academic internship report in our chair group each year. 


\section{Words of thanks}

Let me finish with a few words of thanks. I want to start thanking my former PhD supervisors Jo van Engelen and Lex Bouter for their guidance during my own $\mathrm{PhD}$ trajectory. And Louw Feenstra, the then chairman of the Board of the EMGO institute in Amsterdam, who trusted me to be able to finish my PhD successfully next to my busy job as the Managing Director of the Institute.

At the end of my journey in Wageningen, I want to express my sincere thanks to the Executive Board of Wageningen University. I am proud to have been a member of this university, with its great mission: 'To explore the potential of nature to improve the quality of life.'

In particular, I would like to express my gratitude to my colleagues in the Management Studies Group. It has always been a great privilege working with you, collectively creating a thriving chair group. And my about $40 \mathrm{PhD}$ students, I found it extremely rewarding to work with you and to meet you in your home countries. If you are not here today, I hope you can see me and hear my words by means of WUR TV. Also to all my master students, it has been rewarding working with you and teaching you the scientific background of management practices.

Since the fall of 2015, our research group has been strongly embedded in the Subdepartment of Business Sciences. Numerous joint research projects are conducted and close cooperation exists in the educational programmes. I want to thank my current and former colleagues Hans van Trijp, Alfons Oude Lansink, Bedir Tekinerdogan, and Martin Mulder, recently succeeded by Perry den Brok, Jacqueline Bloemhof and her predecessors, Paul van Beek and Jack van der Vorst, now Director of the Social Sciences Department. I also want to thank Bernd van der Meulen from Law and Governance Group.

I want to thank the Executive Managers and staff of the Wageningen School of Social Sciences, the Educational Directors, student advisors and staff members of the different Education Programmes, the staff of Wageningen Academic Publishers, and the members of the Editorial Board of the Journal of Chain and Network Science for the good cooperation.

I enjoyed having been a member of the Board of 'De WUgenoten', the association of professors of Wageningen University and their partners. 
Outside of the Department of Social Sciences, I have enjoyed many delightful contacts, both nationally and internationally. I am so happy that my international colleagues Stefanie Bröring, Gerhard Schiefer and Xavier Gellynck can be here with us today.

It was a great joy to work together with the staff of the Netherlands Packaging Centre and all the members of the jury of the Gouden Noot. I also appreciated the good cooperation with the staff of Food Valley NL, as well as with the staff and my fellow members in the Supervisory Board of Scholtenszathe Estate.

I also want to thank all managers of the different companies, either large or small, for their willingness to share their insights in open innovation.

And last but not least, I want to thank my family. First of all, my lovely wife Frances, thank you for everything you did for me. Without your support and love, I would not have stood here. Then our children, Anne Willem and Ilonka and their partners, Heba and David, and our grandchildren Liv-Océane and Tibor, I really feel blessed.

In my inaugural address I started by referring to the French physiocrats in the 18th century, who divided the economic world into the 'classe productive', agriculture, and the 'classe sterile', industry and trade. Looking back I can tell you that after more than 17 years as professor at Wageningen University, I am extremely grateful that I could support the 'classe productive'. I hope that I have shown you today that open innovation is the road to success for the agrifood sector. Ladies and gentlemen, thank you all for coming; I really appreciate that very much. But I have said enough, now it is time for drinks and networking. I hope that this will be the beginning of many new open innovation projects!

Ik heb gezegd 


\section{References}

Ahuja, G., 2000. Collaboration networks, structural holes, and innovation: A longitudinal study. Administrative Science Quarterly, 45(3): 425-455

Adner, R. and R. Kapoor, 2016. Innovation ecosystems and the pace of substitution: Re-examining technology S-curves. Strategic Management Journal, 37: 625-648

Annosi, C.M., N.F. Foss, F. Brunetta and M. Magnusson, 2017. The interaction of control systems and stakeholders networks in shaping the identities of selfmanaged teams, Organization Studies 38(5): 619-645

Bornkessel, S., S. Bröring and S.W.F. Omta, 2015. Crossing industrial boundaries at the pharma-nutrition interface in probiotics: a life cycle perspective, PharmaNutrition, 3(4): 29-37

Buisson, D., 1995. Developing new products for the consumer. In: D.W. Marshall (ed.) Food choice and the consumer. Chapman \& Hall, Cambridge, 182-215

Chatenier, E. du, J.A.A.M. Verstegen, H.J.A. Biemans, M. Mulder, and S.W.F. Omta, 2010. Identification of competencies for professionals in open innovation teams, R\&D Management, 30(2): 139-150

Chesbrough, H.W., 2003. Open Innovation: The New Imperative for Creating and Profiting from Technology. Harvard Business School Press, Cambridge Mass.

Chesbrough, H.W., 2017. The Future of Open Innovation. Research. Technology Management, 6o, 35

Chesbrough, H.W., W. Vanhaverbeke and J. West, 2006. Open innovation: Reaching a new paradigm, Oxford University Press, Oxford

Christensen, C.M., M. Raynor and R. McDonald, 2015. Disruptive innovation? Twenty years after the introduction of the theory, we revisit what it does -and doesn't -explain. Harvard Business Review, 44

Churchill, W., 1931. Fifty years hence Strand Magazine, December

Cooper, R.G., 1999. From experience: the invisible success factors in product innovation, Journal of Product Innovation Management, 16(2): 115-133 
Denolf, J.M., P.M. Wognum, J.H. Trienekens, J.G.A.J. van der Vorst and S.W.F. Omta, 2015. Towards a framework of critical success factors for implementing supply-chain information systems, Computers in Industry, 68: 16-26

Ebersberger, B. and Herstad, S.J., 2011. Product innovation and the complementarities of external interfaces. European Management Review, 8(3): 117-135

Enzing, C.M., M.H. Batterink, F.H.A. Janszen and S.W.F. Omta, 2011. Where innovation processes make a difference in products' short- and long-term market success, British Food Journal, 113(7): 812-837, Emerald Literati Network Outstanding Paper Award 2012

European Commission, 2016. A strategic approach to EU agricultural research \& innovation. Final Paper, outcome of the European Conference: "Designing the path", 26-28 January, Brussels

Flipse, S.M., M.C.A. van der Sanden, T. van der Velden, F.T.J.M. Fortuin, S.W.F. Omta and P. Ossewijer, 2013. Identifying Key Performance Indicators in Food Technology Contract R\&D, Journal of Engineering and Technology Management, 30: 72-94

Fortuin, F.T.J.M. and S.W.F. Omta, 2009. Innovation drivers and barriers in food processing, British Food Journal, 111(8): 839-851

Fortuin, F.T.J.M. and S.W.F. Omta (eds.), 2014. NetGrow Toolbox. Tools for open innovation in the food industry, 2014, EU, ISBN 979-808-160-93-95, 32

Foss, N., T. Pedersen, J. Pyndt and M. Schultz, 2012. Innovating organization \& management, new sources of competitive advantage. Cambridge University Press, Cambridge

Frank, S., P. Havlik, J.-F. Soussana, A. Levesque, H. Valin, e. Wollenberg, U. Kleinwechter, O. Fricko, M. Gusti, M. Herrero, P. Smith, T. Hasegawa, F. Kraxner and M. Obersteiner, 2017. Reducing greenhouse gas emissions in agriculture without compromising food security? Environmental Research Letters, 2017; 12 (10), 14

Garbade, P.J.P., S.W.F. Omta and F.T.J.M. Fortuin, 2013. Exploring the characteristics of innovation alliances of Dutch Biotechnology SMEs and their policy implications, Biobased and Applied Economics, 2(1): 91-111 
Gerritsma, F. and S.W.F. Omta, 1998. The Content Methodology.

Facilitating performance measurement by assessing the complexity of R\&D projects, in Management of Technology, Sustainable Development and Eco-efficiency, Pergamon, Elsevier Science Ltd, Amsterdam etc., pp. 101-110, Best Paper Award

Gilsing, V. and B. Nooteboom, 2006. Exploration \& exploitation in innovation systems. Research Policy, 35(1): 1- 23

Gilsing, V., B. Nooteboom, W. Vanhaverbeke, G. Duysters and A. van den Oord, 2008. Network embeddedness and the exploration of novel technologies: Technological distance, betweenness centrality and density. Research Policy, 37(10): 1717-1731

Godin, B., 2017. Models of Innovation. The History of an Idea. MIT press, pp. 344

Grandori, A., 2001. Neither hierarchy nor identity: Knowledge-governance mechanisms and the theory of the firm, Journal of Management and Governance, 5: $381-399$

Griffin, A., 1997. PDMA Research on new Product Development Practices: Updating Trends and Benchmarking Best Practices, Journal of Product Innovation Management, 14: 429-458

Grekova, E., H.J. Bremmers, J.H. Trienekens, R.G.M. Kemp and S.W.F. Omta 2014. Extending environmental management beyond the firm boundaries. An empirical study of Dutch food and beverage firms. International Journal of Production Economics, 152: $174-187$

Grekova, E., R.J. Calantone, H.J. Bremmers, J.H. Trienekens and S.W.F. Omta 2016. How environmental collaboration with suppliers and customers influences firm performance: Evidence from Dutch food and beverage processors, Journal of Cleaner Production, 112: $1861-1871$

Griffin, A., 1997. PDMA Research on new Product Development Practices: Updating Trends and Benchmarking Best Practices. Journal of Product Innovation Management, 14, 429-458.

Gulati, R. and S.B. Srivastava, 2014. Bringing agency back into network research. Brass, D. (ed.) Contemporary Perspectives on Organizational Social Networks (40) Emerald Group Ltd., 73-93 
Hamel, G. and Prahalad, C.K., 1994. Competing for the Future. Harvard Business School Press, Boston, Mass.

Hasler, K., H.W. Olfs, S.W.F. Omta and S. Bröring, 2016. Drivers for adoption of eco-innovations in the German fertilizer supply chain, Sustainability, 8(8):16

Haverkamp, D.J. H.J. Bremmers, and S.W.F. Omta, 2010. Stimulating environmental management performance. Towards a contingency approach, British Food Journal, 112 (11): 1237-1252

Hollander, J., 2002. Improving performance in business develop $\neg$ ment: Genesis, a tool for product development teams, PhD thesis, University of Groningen

Jamrog, J.J., 2006. The Quest for Innovation: A Global Study of Innovation Management 2006-2016, Human Resource Institute, University of Tampa, Tampa, Fl.

Janssen K.L., 2011. Driving the food market. Proactive consumer involvement to support radical product innovation, PhD thesis, Radboud University Nijmegen

Khodaei, H., V.E. Scholten, E.F.M. Wubben and S.W.F. Omta, 2016. Entrepreneurship and prior experience as antecedents of absorptive capacity of high-tech academic spin-offs, Journal on Chain and Network Science, 16 (2): 95-115

Kühne, B., 2010. Understanding innovation capacity in food chains. The European traditional food sector, $\mathrm{PhD}$ thesis, University of Ghent

Knudsen, M.P., 2007. The relative importance of interfirm relationships and knowledge transfer for new product development success. Journal of Product Innovation Management 24(2): 117-138

Koka, B., R. Madhavan and J. Prescott, 2006. The evolution of interfirm networks: environmental effects on patterns of network change. Academy of Management Review, 31(3): 721-727

Lord, J.B., 2000. New Products failure and success. In: Brody, A.L. and J.B. Lord, (eds.), Developing new products for a changing market place. Technomic, Lancaster, 55-96 
Liu, Z., M.A. Jongsma, C. Huang, J.J.M. Dons and S.W.F. Omta, 2015. The Sectoral Innovation System of the Dutch Vegetable Breeding Industry, Wageningen Journal of Life Sciences (NJAS), 74-75: 27-39

Lubberink, R., V. Blok, J van Ophem and S.W.F. Omta, 2017. Lessons for responsible innovation in the business context: A systematic literature review of responsible, social and sustainable innovation practices, Sustainability, 9(5): 32

Materia, V.C., S. Pascucci, S. and L. Dries, 2017. Are in-house and outsourcing innovation strategies correlated? Evidence from the European agri-food sector, Journal of Agricultural Economics, 68(1): 249-268

Medeiros, G.I.B. de, B. Erlaine and T.J. Florino, 2016. Open innovation in agrifood chain: A systematic review, Journal of Technology Management and Innovation, 11(2): 127-136

Mytelka, L.K. and S. Goertzen, 2008. In: The Handbook of Innovation in the Food and Drink Industry, R. Rama (Ed.), 428

Nooteboom, B., 2004. Governance and competence: How can they be combined? Cambridge Journal of Economics, 28(4): 505-525

Nuhoff-Isakhanyan G., E. Wubben, S.W.F. Omta and S. Pascucci 2017. Network structure in sustainable agro-industrial parks, Journal of Cleaner Production, 141: 1209-1220

OECD, 2015. Innovation, agricultural productivity and sustainability in the Netherlands, OECD Food and Agricultural Reviews, OECD Publishing, Paris

Omta, S.W.F. and W. van Rossum, 1999. The Management of Social Capital in R\&D Collaborations. In: Corporate Social Capital and Liability, Kluwer Academic Publishers, Boston, Dordrecht, London, 356-376

Omta, S.W.F. and P. Folstar, 2005. Integration of innovation in the corporate strategy of agri-food companies, in Innovation in agri-food systems, 2nd ed., Wageningen Academic Publishers, 223-246

Omta, S.W.F., F.T.J.M. Fortuin and N.C. Dijkman, 2013. Open innovation in the food industry: an evidence based guide, EU, 64 
Omta, S.W.F., F.T.J.M. Fortuin and N.C. Dijkman, 2017. Comparing Open Innovation of Innovative Food SMEs with SMEs in the Seed and High Tech Industries, in: Open Innovation and Knowledge Management in Small and Medium Sized Enterprises, Eds.: S. Durst and S. Temel, pp. 23

Osterwalder, A. and Y. Pigneur, 2010. Business Model Generation: A handbook for visionaries, game changers, and challengers. Wiley \& Sons, 288

Owen, R., J. Stilgoe, P. Macnaghten, M. Gorman, E. Fisher, and D. Guston. 2013. A framework for responsible innovation. In Responsible innovation: Managing the responsible emer $\neg$ gence of science and innovation in society, ed. R. Owen, J. Bessant, and M. Heintz, 27-50. Chichester: Wiley.

Phelps, C.C., 2010. A longitudinal study of the influence of alliance network structure and composition on firm exploratory innovation. Academy of Management Journal, 53(4): 890-913

Ploum, L., V. Blok, T. Lans and S.W.F. Omta 2017, Self-interest versus selftranscendence. An empirical approach to moral competencies and their role in the sustainable entrepreneurial process. Journal of Business Ethics.

Rama, R. (ed.), 2008. Handbook of Innovation in the Food and Drink Industry, Haworth Press, New York

Rudolph, M.J., 1995. The food product development process. British Food Journal 97: 3-37

Sabidussi, A., B. Lokshin, T. de Leeuw, G. Duysters, H.J. Bremmers, and S.W.F. Omta, 2014. A comparative perspective on external technology sourcing modalities. The role of synergies, Journal of Engineering and Technology Management, 33: 18-31

Sarkar, S. and A.I.A. Costa, 2008. Dynamics of open innovation in the food industry, Trends in Food Science \& Technology 19: 574-580

Scholten, V., T. Elfring, R. Kemp and S.W.F. Omta, 2015. Bridging ties and the role of research and start-up experience on the early growth of Dutch academic spin-offs, Technovation, 45-46: 40-51

Schumpeter, J.A., 1934. Theory of Economic Development. Harvard University Press, Cambridge, Mass. 
Stevens, G.A. and Burley J., 1997· 3,000 Raw Ideas = 1 Commercial Success! Research. Technology Management 4O(3), 16-27

Tasselli, S., M. Kilduff and J.I. Menges, 2015. The micro-foundations of organizational social networks, a review and an agenda for future research. Journal of Management. 41(5): 1361-1387

Teece, D.J., 1986. Profiting from technological innovation. Implications for integration, collaboration, licensing and public policy, Research Policy, 15: 285-305 Teece, D.J., 2007. Explicating dynamic capabilities: the nature and microfoundations of (sustainable) enterprise performance. Strategic Management Journal, 28(13): 1319-1350

Telem, R.S., S.H. Wani, N.B. Singh, R. Nandini, R. Sadhukhan, S. Bhattacharya and N. Mandal, 2013. Cisgenics. A Sustainable Approach for Crop Improvement. Current Genomics, 14(7): 468-476

Tepić, M., R. Kemp, S.W.F. Omta and F.T.J.M. Fortuin, 2013. Complexities in innovation management in companies from the European industry: A path-model of innovation project performance determinants, European Journal of Innovation Management, 16(4): 517-549

Tidd, J. (ed.), 2014. Open innovation, research, management and practice. Series on Technology Management, Vol. 23, Imperial College Press

Tidd, J., Bessant, J., and Pavitt, K., 2001. Managing Innovation: Integrating Technological, Market, and Organizational Change, 3rd ed., John Wiley \& Sons, New York

Traitler, H., H.J. Watzke and I.S. Saguy, 2011. Reinventing R\&D in an open innovation ecosystem, Journal of Food Science 76(2): 62-68

Triguero, Á, Córcoles, D., Cuerva, M.C. 2013. Differences in innovation between food and manufacturing firms: An analysis of persistence, Agribusiness, 29: 273-292

Von Hippel, E., 1988. The Sources of Innovation. Oxford University Press, Oxford Verbeke, W.P. Sans and E.J. van Loo, 2015. Challenges and prospects for consumer acceptance of cultured meat, Journal of Integrative Agriculture, 14(2): 285-294 
Wever, M., N. Wognum, J.H. Trienekens and S.W.F. Omta, 2012. Supply chain-wide consequences of transaction risks and their contractual solutions: towards an extended Transaction Cost Economics framework, Journal of Supply Chain Management, 48(1): 73-92, Harold E. Fearon Best Paper Award 2012

Wubben, E.F.M, M. Batterink, C. Kolympiris, R. Kemp and S.W.F. Omta, 2015. Profiting from external knowledge: the impact of different external knowledge acquisition strategies on innovation performance, International Journal of Technology Management, 69(2): 139-165 


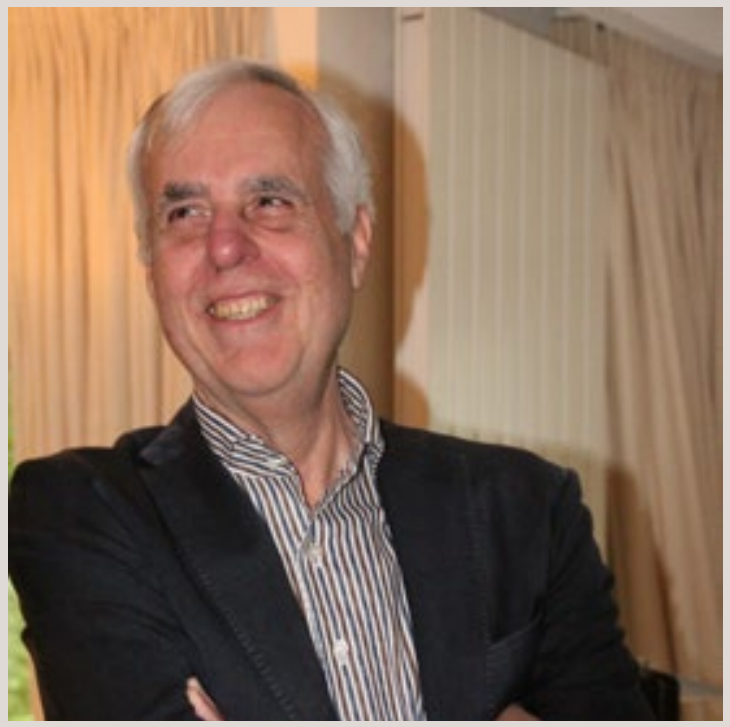

Prof.dr S.W.F. Omta

Open Innovation, the Road to Success in Agrifood?

The world has developed into a network economy in which the long-term success of firms is increasingly dependent on open innovation, the degree to which they are able to collaborate in domestic and international networks. This also holds for the agrifood sector, long regarded as a low tech sector, and it is clear that the importance of open innovation will only grow in the future taking into account the fast developments in cellular agriculture, vertical farming and big data. 